\title{
Habits of Democracy: A Deweyan Approach to Citizenship EdUCATION In AmERicA TOdAY
}

\section{Sarah M. Stitzlein}

Throughout his works, John Dewey makes deep and intriguing connections between democracy, education, and daily life. His ideas have contributed to both the theory and practice of participatory democracy and, although he actually "had surprisingly little to say about democratic citizenship" directly, his scholarship has influenced the ideas of others working on citizenship education and has provided rich notions of democracy, education, experience, and public life underlying it. ${ }^{1}$ However, Dewey commentators Michael Eldridge and Robert Westbrook worry that, although Dewey promoted deeper ways of participating in democracy and engaging in social life, he failed to fully explain how to achieve his vision. ${ }^{2}$ Instead, he alluded to the need for developing democratic habits through "continuous social planning," ${ }^{\text {"3 }}$ without detailing what those habits are or how to acquire them.

In some regards, this fits with Dewey's pragmatist spirit to the extent that he would not want to pin down specific habits or guidelines outside of particular real-life contexts. In examining today's social and political contexts, we discover environmental elements that both support and work against deep, participatory democracy. Though declining youth political participation has been documented for many years, we've recently seen increasing numbers of youth interested in presidential elections, ${ }^{4}$ participating in political life, ${ }^{5}$ and discussing important social issues like wars and education reform. ${ }^{6}$ We have also witnessed a resurgence of citizens taking to the streets in political protest through movements like Occupy Wall Street and the Tea Party. At the same time, pragmatist Judith Green warns, "dangerous habits of daily living have become increasingly widespread-constant busyness, fashionable cynicism, reliance on experts, willful ignorance of our nation's history and of current events, materialism, personal greed, and, especially since September 11, feelings of 'ontological insecurity,' generalized anxiety, and personal impotence." In a Deweyan voice, Gregory Fernando Pappas adds, "Of all the problems of democracy, the one that strikes me as most urgent today is simply that democracy is not experienced as a task or problem. This happens when it is taken for granted, or worse, when many people have no ideal or sense of how things could be better. Without awareness that there is a crisis of democracy, there is not the felt, problematic situation that can lead to inquiry about how to ameliorate present conditions." ${ }^{\prime}$ The current socio-political environment provides contradictory 
experiences for children and adults that may fail to nurture the ways of democratic life needed to keep American democracy vibrant if, indeed, they even notice the crisis of democracy at all.

I will argue in this paper that certain democratic habits should be nurtured through a supportive, formative culture, both inside and outside of schools, in order to best achieve healthy democratic life in the present environment. My aim here is to provide a partial response to the basic criticism of Eldridge and Westbrookpartial insofar as I do so not only in a pragmatist fashion tied to today's context, but also with a Deweyan spirit of recognizing the importance of not specifying democratic practices too narrowly in advance. I will fill some of the gaps in the picture of democracy that Dewey paints, employ Dewey's own unique understanding of habits as means for developing and practicing democracy, and suggest some fruitful avenues for citizenship education in today's social and political context.

\section{DeWEYAN DeMOCRACY}

While Dewey had much to say about what good democracy should be, it is wise to begin this inquiry with his warning that democracy "has to be constantly discovered, and rediscovered, remade and reorganized." In this way, democracy itself is constantly changing to meet the changing needs of the people and fit the environment in which it is enacted. As a way of life that is adapted to meet the needs of citizens, were democracy to be pinned down once and for all, it would no longer be useful and would no longer entail the active participation that is integral to its viability.

Rather than merely a formal system of government, democracy, for Dewey, was as a way of life that guides one both personally and in interactions with others. Dewey's social definition of democracy as a "mode of associated living"10 foregrounds the importance of collective decision-making and the building of social intelligence through group problem-solving, communication, and the sharing of experiences. But more than this, his model of how one's personal democratic identity-composed of one's habits, dispositions, and beliefs-works in a social framework reveals the importance of ongoing social and political action that sustains and enhances collective democratic life.

For Dewey, democracy is both an end and a means. It is a way of life that we strive to achieve, but in order to do so, our day-to-day practices must themselves also be democratic. This includes the way that children are educated to be good citizens. We cannot indoctrinate them into seeing democracy as an admirable end goal while engaging in classroom practices that are totalitarian. Rather, we must employ means that are aligned with the end, allowing students to engage in collective problem-solving, inclusive communication, and shared governance as we rear them for the role of citizen. The thoughts and habits developed in this process are themselves open to change and influence from students, thereby allowing 
democracy to transform across time, rather than limiting children to a predetermined sense of democracy or good citizenship.

James Scott Johnston rightly explains how to guide students in nonindoctrinating ways: "Social control is present in the educative process, but it is a means only, not an end. It serves to guide and direct the child's own process of inquiry such that she, once the inquiry is habitualized and developed, has the capacity to determine for herself whether or not to value or participate in certain social activities. It is a necessary means to what Dewey terms 'freedom."'11 Later he adds, "When inquiry is fostered, the sort of freedom antithetical to indoctrination is equally fostered. To educate the habits of inquiry is to educate for democracy."'12 While careful not to be too specific, Dewey does highlight some beliefs that encourage democracy as he sees it. These include beliefs in equal opportunity, free communication, inclusion of varied perspectives, hope for a better future, and valuing life uncoerced by others. ${ }^{13}$

\section{DEWEYAN HABITS}

All people have impulses. These natural energies are shaped and collected into habits as individuals transact with the world around them, especially in regards to cultural norms, and when they engage in the process of inquiry. These ways of being are largely practiced without effort or conscious attention. They are the dispositions, sensitivities, and ways of acting and communicating that enable us to live comfortable lives that operate smoothly. Importantly for Dewey, habit should be understood as a predisposition to act, or sensitivity to ways of being-rather than the more common understanding of habit as an inclination to repeat identical acts or address content precisely. In Dewey's words, "All habits are demands for certain kinds of activity; and they constitute the self. In any intelligible sense of the word will, they are will. ${ }^{\prime 14}$ Habits are active and energetic means that project themselves. ${ }^{15}$

Habit, as the will to act, engages with the world in ways that allow us to pursue desires. This is possible, in part, because habits "do all the perceiving, recognizing, imagining, recalling, judging, conceiving and reasoning that is done."16 Habits provide the mechanisms that enable or enhance reasoning, as well as carry out the activities that might result from reasoning. Habits filter and organize our perceptions, determining which environmental objects are noted and in what way. Habits, then, shape and precede the generation of ideas. They provide us with know-how, "working capacities" that help us know how to act in the world. ${ }^{17}$

There is a reciprocal relationship between habit and thought. Habits provide us a way to embody thoughts in the world, where they can be tested out and improved. Then, reflective thought about one's actions allows for new and better habits to be developed. So rather than seeing habit as something merely routine and unconscious, for Dewey, habit is closely related to intelligence, for habits are brought into consideration whenever a problematic situation must be addressed or new conditions arise. 
When formed tentatively as hypotheses in light of intelligent foresight into future, unpredictable circumstances, habits can be flexible agents of change whose form emerges as situations unfold. Or, in Dewey's words, "the intellectual element in a habit fixes the relation of the habit to varied and elastic use, and hence to continued growth." ${ }^{18}$ In this way, habits, as intimately tied to intelligent reflection, are projective and sites of agency. They can be changed in ways that change the subject and, through transaction with the environment, can effect change in the world as well. The heart of agency lies in the process of acquiring new habits and changing old ones. ${ }^{19}$

Sometimes, in the course of intelligent reflection in trying out a habit, it is revealed that the habit is somehow problematic. In the context of democracy, this might be a habit that is stagnant and doesn't keep up with the changing demographics of population, is exclusionary, doesn't serve social needs, blocks exchanges with others, or is unjust. We cannot easily drop bad habits, but we can work through a process of changing them and replacing them with better habits, such as habits that are more just or inclusive. Ideally, because habits are "adjustments of the environment, not merely to it," adopting new habits (through a careful process of intellectual reflection as well as other means) can alter the environmental phenomena that produced the problematic, old habit, in this case possibly enhancing democratic processes. ${ }^{20}$

Habits are developed as individuals transact with the world around them - as they shape and are shaped by other people, traditions, practices, and experiences. While each person's collection and enactment of habits is unique, many habits are more or less shared because they result from analogous transactions with the environment. Because these habits are shared across groups of people, they become customs-typical ways of behaving within a social group, thereby reinforcing the development of similar habits in younger generations.

There has been a tendency by political theorists to discuss civic virtues in their work on citizenship education. ${ }^{21}$ Certainly, there are some affinities between habits and virtues. Habits are traits of character that are categorized as positive or negative, virtues or vices. ${ }^{22}$ But we should not limit this normative judgment to a specific ethical framework or defined judgments on the moral uprightness of one's traits. Nor should we reduce moral behavior to the presence or enactment of one particular habit or small set of habits. Virtues are moral because they are tied to other habits. In Dewey's words, "To call them virtues in their isolation is like taking the skeleton for the living body. The bones are certainly important, but their importance lies in the fact that they support other organs of the body in such a way as to make them capable of integrated effective activity. And the same is true of the qualities of character which we specifically designate virtues. Morals concern nothing less than the whole character."23

The categorization and measure of habits extends beyond an ethical framework. I agree with Shane Ralston, who contends, "Indeed, both values and habits 
can be evaluated naturalistically, instrumentally, or conventionally (LW 7, 285309). Yet, the ultimate test of a habit's value is whether it directs inquiry in fruitful ways - that is, in ways that fund experience with meaning, render new connections, create helpful tools for future inquiries, and develop the inquirer's native abilities." ${ }^{24}$ Rather than following a specific moral path, habits shape our inquiries and, in turn, we employ inquiry to revise our habits when new (problematic) situations arise. Habits, seen through the lens of virtues, are closely tied to inquiry, democracy, and education. Pappas rightly explains, "Since certain habits and dispositions are our main tools, as well as the most controllable factors we have, we can hope for amelioration by encouraging certain virtues. Philosophical inquiry into the possible conditions of improvement is not the search for one set of habits that will solve all of our problems, or that will help anyone in any situation. Nor is the task to find those dispositions and attitudes that will lead us to the good life; rather, the task is to find those which offer some reliability for achieving a better life." 25 We can tentatively outline some habits that are more reliable for achieving democracy than others, as I will show in the following sections.

Habits are acquired in many different types of social settings, but their cultivation is often most overt in schools, where children watch, imitate, and interact with others as they learn about socially acceptable behaviors and societal traditions, through both direct and indirect means. It is also under the guidance of teachers and oversight of the process of inquiry that children can best learn to use the relationship between thought and habit to improve themselves and their practice of democracy.

Gert Biesta describes a flaw with citizenship education derived from the Enlightenment as "an individualistic approach to democratic education, one in which the educational efforts are focused on equipping individuals with the proper set of democratic knowledge, skills and dispositions, without asking questions about individuals' relationships with others and about the social and political context in which they learn and act." ${ }^{26}$ Biesta worries that the educational implications of Dewey's social account of the subject also fall victim to this flaw. I contend that, although habits for Dewey are individually held and living democratically is a deeply personal endeavor, Dewey's view of the formation of habits and their practice as inherently social and transactional prevents resulting calls for citizenship education from being problematically individualistic. Such citizenship education must be thoroughly social. It must employ democratic means to achieve democratic ends. In this way, rather than merely educating for democracy - as something to be achieved by graduates at some distant point in time-Dewey's view of habit formation and change demands educating through democracy, while also preparing children for their future roles as citizens. ${ }^{27}$

Furthermore, Dewey notes, "democracy is a personal way of individual life; ... it signifies the possession and continual use of certain attitudes, forming personal character and determining desire and purpose in all the relations of life. Instead of thinking of our own dispositions and habits as accommodated to certain 
institutions we have to learn to think of the latter as expressions, projections and extensions of habitually dominant personal attitudes."28 So while democracy and the development of citizenship may ultimately boil down to individuals, those individuals can never be abstracted from their social contexts-their acts always have social or political impact, and their habits have the capacity to shape the practice of democracy and its institutions.

Our identities as citizens are not individual understandings, nor are they constituted only by a sense of membership. Instead, these identities are deeply social, for our intelligence and our identities are formed through transactions with others. Our understandings of ourselves as citizens are centrally about our lives as actors in the social and political arena where we engage our habits.

\section{EXPERIENCE to Nurture Habits ANd Democracy}

Dewey pointed out in "Creative Democracy" that we have often assumed democracy will simply continue over time. This is largely because we tend to think of democracy as something that exists somewhere else, typically in Washington, DC, or the state capitol, and is supported by the voting of dutiful individuals. We don't think of it as something that directly involves us or our daily lives. To keep democracy healthy, we must transform this way of thinking. We have to see that democracy's maintenance and improvement depend upon our active daily participation in the ways we interact with others, build social knowledge, solve problems, and uphold a common good.

As Robert Talisse and others who have built upon Deweyan philosophy in their calls for citizenship practice argue, we must recognize the need for a formative culture. ${ }^{29}$ Such a culture supports the development of democratic habits through the requisite experiences, and intelligent reflection on those experiences by its citizens. This should be a culture that extends well beyond school walls, a culture that not only supports the development of those habits, but that also responds to them as they are created. Moreover, it can be enhanced by paying attention to the cares, actions, and expressions of its young citizens. Dewey brings together experience, education, and democracy when he argues,

So stated, democracy is belief in the ability of human experience to generate the aims and methods by which further experience will grow in ordered richness. Every other form of moral and social faith rests upon the idea that experience must be subjected at some point or other to some form of external control; to some 'authority' alleged to exist outside the processes of experience. Democracy is the faith that the process of experience is more important than any special result attained, so that special results achieved are of ultimate value only as they are used to enrich and order the ongoing process. Since the process of experience is capable of being educative, faith in democracy is all one with faith in experience and education. ${ }^{30}$

\section{E\&C Education and Culture}


For Dewey, experience is all-encompassing, involving the entire individualmind, body, reason, thoughts, habits, and emotions-as well as the socio-cultural environment. Educative experience "arouses curiosity, strengthens initiative, and sets up desires and purposes that are sufficiently intense to carry a person over dead places in the future."31 These experiences lead to growth and provide continuity, while bad or uneducative experiences prevent growth, stifle interest in the world, produce bad attitudes, or fail to compliment the individual's changing world. This conception of growth illustrates how experiences can develop our physical, intellectual, and moral capacities-actualizing these capacities and helping them to inform one another so that they continue into the future (though not necessarily in linear fashion). The movement invoked by such experience compounds upon itself, where it is expressed as growth.

Whereas critics Boyd Bode, Randolph Bourne, and John Patrick Diggins have faulted Dewey for not defining an end goal for growth, Robert Talisse contends that growth is oppressive and non-democratic, and Shane Ralston fears that institutionalized practices of inquiry may operate paternalistically and be seen as aligned with a politically Left agenda, I side with James Scott Johnston, who demonstrates the connection between habits, experience, growth, inquiry, and democracy, thereby providing criteria for growth while also allowing for openness and self-direction. ${ }^{32}$ Moreover, Johnston rightly argues that developing habits of inquiry is precisely the type of education (and in the present case, citizenship education) that works against indoctrination or a particular political agenda, insofar as inquiry and the inclination to ask questions and critically investigate make all views fodder for consideration. He writes,

Dewey opposed any sort of education that would result in passivity, indoctrination, and dogma. These are foreclosed by Dewey's insistence that education equals growth, and that growth ex hypothesi cannot be yoked to any fixed agenda or belief. It will do to highlight again the role that education plays in fostering growth. In so doing, the stage is set for the further argument that it is (in part) inquiry that is being developed in growth, and that education, inasmuch as it implies growth, equally implies inquiry. Further, as inquiry is social, the education of the child as an individual and a social being implies equally the development of inquiry. Developing inquiry is the development of the individual such that she can participate fruitfully as a democratic being in a democratic community. Education thus becomes a necessary constituent of growth, community, and democracy, by fostering the habits of inquiry, which (again) fosters the movement of growth to community, to democracy, and back again. ${ }^{33}$

Moreover, we cultivate habits by providing environments and experiences that are conducive to their use and success: 
The development within the young of the attitudes and dispositions necessary to the continuous and progressive life of a society cannot take place by direct conveyance of beliefs, emotions, and knowledge. It takes place through the intermediary of the environment...It is truly educative in its effect in the degree in which an individual shares or participates in some conjoint activity. By doing his share in the associated activity, the individual appropriates the purpose which actuates it, becomes familiar with its methods and subject matters, acquires needed skill, and is saturated with its emotional spirit. ${ }^{34}$

Developing habits of democracy, then, would likely necessitate immersing individuals in practices of shared living where those habits serve their needs well. Sometimes this process is bolstered by the guidance of teachers and other leaders, who help individuals participate in the process of inquiry about the world and reflect on the role of their habits.

While the experiences that nurture and sustain democracy extend well beyond schools, I limit myself to the context of school in this paper. Schools provide an environment and social institution that help children acquire habits. Moreover, they are spaces where intelligent inquiry about cultural norms and ways of life can shape and improve habits. Schools can respond to the customs of a democratic society and incorporate those customs into their practices, even improving them in some cases. As they shape the habits of future generations, they shape future customs. Schools can provide a space that sustains public life by teaching young people how to be part of it: ${ }^{35}$

Just as Dewey's democratic ideal has no fixed and final content but rather unfolds its meaning in response to the growth of historical experience and understanding of a people whose form of life creates and is guided by it, so the content of the educational processes that serve as means to and measures of the democratic ideal must change in response to past experiences and new needs within emerging problem situations of the present and the foreseeable future. ${ }^{36}$

Given this, I offer some insight into our current context and needs in order to highlight some of the habits that schools should be nurturing to sustain and improve existing democracy, while at the same time recognizing that the educational approaches and goals themselves must be open to change.

\section{HaBITS OF DEMOCRACY}

Too often citizenship education is construed as socializing children into the image of an ideal citizen. While there are likely some traits of good citizens that will withstand the test of time, we cannot know just what shape citizenship will take as democracy changes to meet the needs of its environment and constituents. ${ }^{37}$ Dewey rightly warns, 
With the advent of democracy and modern industrial conditions, it is impossible to foretell definitely just what civilization will be twenty years from now. Hence it is impossible to prepare the child for any precise set of conditions. To prepare him for the future life means to give him command of himself; it means so to train him that he will have the full and ready use of all his capacities; that his eye and ear and hand may be tools ready to command, that his judgment may be capable of grasping the conditions under which it has to work, and the executive forces be trained to act economically and efficiently. ${ }^{38}$

What we can do, then, is to advocate political agency, via the formation of democratic habits and the capacity for change, as a way to provide youth starting points for their paths to a citizenship that will transform across their lifespans. As I have argued elsewhere, ${ }^{39}$ habits themselves should be flexible, and therein lies one of their most significant democratic implications: they can be adapted for an unknown social future. Given this, I provide here not an all-inclusive list of specific habits of good citizenship, but rather highlight some of the habits that most need attention or could best serve the demands of our current democracy, anticipating a future where they will continue to be of use and readapted.

\section{Citizenship as Shared Fate}

Throughout the twentieth century, civics courses were required in many American schools. One of their primary aims was to promote patriotism as an allegiance to and pride in our nation-state. Following the attacks of 9/11, patriotic expectations of schools and citizens, especially in terms of support for the military, ran particularly high. ${ }^{40}$ Some schools placed greater emphasis on the daily Pledge of Allegiance, while others engaged in service projects to support the troops. Citizenship education scholar Joel Westheimer reports that a 2004 video called "Patriotism and You," developed by the Committee for Citizen Awareness, has been viewed in thousands of classrooms. This video calls for unwavering commitment to the United States and emphasizes the need for national unity, especially during times of war. ${ }^{41}$ In a review of popular social studies textbooks, similar messages encouraging nationalistic pride were prominent. ${ }^{42}$ It is therefore unsurprising that of the 2,366 seniors who completed the California Survey of Civic Education in 2005, 22\% agreed with the statement "It is un-American to criticize this country," while $21 \%$ had a neutral response to the statement. ${ }^{43}$ More recently, some districts, such as Hall County Schools in Georgia, have called for revamped social studies curricula that emphasize American pride and celebration of American exceptionalism. ${ }^{44}$ While this renewed emphasis on patriotism in schools has generally appeared to decrease in the decade since the United States was attacked, its relatively recent resurgence and continued role in the ongoing war on terror remain significant. 
Patriotism, I contend, can become a bad habit. It can become problematically stagnant, as an unquestioning loyalty to a fixed nation-state. It can become an unthinking and unreflective allegiance that doesn't change to reflect shifts in the nature of the nation-state, its role in military misadventures abroad, or the changing demographics of the country. Instead, I support nurturing a habit of "citizenship as shared fate." ${ }^{35}$ Citizenship as shared fate works as a habit in that it frames how we understand and interpret experiences and events, leading us to see how they impact us as members of a community. It entails an inclination to care about all people in our communities, even those who are different from us or who don't adhere to a single unifying ideology. And that inclination, one aligned with a sense of social responsibility, leads to actions and desires to work in the best interests of the group. Citizenship as shared fate can still provide a sense of "us," and pride in that identity, but it is an affinity that is more readily reconsidered and open to change.

Just as Americans are experiencing pressures regarding patriotism, many are also dealing with the conflicting challenges of globalization. Technology, communication, and the economy have drawn people from around the world together in new ways, changing the meaning of national belonging and rendering traditional patriotic citizenship no longer appropriate. Citizenship as shared fate helps to create bridges of concern between people even if their geographic homes are far apart. It causes citizens to think about and act in the interest of those in their local communities, but also to consider how their actions impact those abroad. This habit can offset some of the negative tendencies of globalization, for instance by increasing the humanist concern for the well-being of those who may face greater inequality and injustice under less regulated free-market capitalism. It also includes a sense of "us" that can help sustain publics in the face of individual competition spurred by the neoliberal economics of globalization.

One way a teacher might nurture the habit of citizenship as shared fate would be to engage students in analyzing and acting upon an issue of economics and/or environmentalism in the community, perhaps whether to buy produce from local farmers or the supermarket, or whether allowing fracking on private land may provide the income needed to keep a family farm operable. Students would be guided to see how multiple parties are implicated in the causes of the problem, and how the issue impacts different people in different places in various ways. Teachers could highlight particular struggles and injustices that students might not have anticipated so that they develop a proclivity to care about how their economic and environmental decisions impact others. This experience provided in the classroom should help students to envision connections to farmers, grocers, hungry people, energy corporations, and others in their community, thereby building a sense of the "us" impacted by the decision of where to shop or whether to drill for natural gas. 


\section{Collaboration and Compromise}

When democracy is understood as majority rule through the aggregation of voting preferences, there is little need for compromise. Voters merely assert their views through their ballots and, if so motivated, may try to persuade others to do likewise so that their view will garner the largest number of votes. Some propositions may be tempered slightly to acquire more votes, but there is little genuine exchange or negotiation between those with competing views. When democracy is understood as participatory, as Dewey viewed it, citizens should be working together to construct ideas and solutions. This process necessarily entails collaboration and compromise, where citizens work together to develop social knowledge and power. ${ }^{46}$ But compromise should not be narrowly understood here as negotiation or making concessions in order to reach an agreement. Rather, "Taking a part in a discussion where we imaginatively enter into the experience of the other requires more than that we meet each other halfway. What we want is a deeper interaction ... where members reexamine their values and interests in light of all others. ${ }^{{ }^{37}}$

Emphasizing collaboration and compromise is not to say that democratic life is easy and conflict free, but a commitment to living democratically includes a commitment to working together. Dewey notes, "A genuinely democratic faith in peace is faith in the possibility of conducting disputes, controversies and conflicts as cooperative undertakings in which both parties learn by giving the other a chance to express itself." ${ }^{38} \mathrm{He}$ adds,

Democracy as a way of life is controlled by personal faith in personal dayby-day working together with others. Democracy is the belief that even when needs and ends or consequences are different for each individual, the habit of amicable cooperation - which may include, as in sport, rivalry and competition-is itself a priceless addition to life. To take as far as possible every conflict which arises - and they are bound to arise - out of the atmosphere and medium of force, of violence as a means of settlement into that of discussion and of intelligence is to treat those who disagree - even profoundly — with us as those from whom we may learn, and in so far, as friends. ${ }^{49}$

In our current context, however, rather than people working together, the American tradition of rugged individualism and contemporary neoliberalism increasingly combine to emphasize the competitive role of the individual, seeking private gains, sometimes at the expense of others, and often consuming goods rather than interacting with other people to find pleasure or solve problems. This outlook has begun to influence school choice movements and for-profit charter schools, where schools are marketed to fulfill the economic interests of individual students rather than to achieve larger social purposes. ${ }^{50}$ In this regard, we see greater emphasis on individuals, particularly in economic terms, rather than on the common good 


\section{Sarah M. Stitzlein}

in social or political terms. Individuals are being prepared to compete against and consume alongside each other. Some parents contribute to this climate by seeking educational hierarchies that serve to distinguish their child from others, thereby conveying social mobility and other privileges that benefit their child and do little to benefit collective knowledge or well-being. ${ }^{51}$

Beyond the school walls, thousands of people across America have recently taken to the streets in political protest. Spurred by nationwide movements, citizens have been sharing their views and leveraging the system for change. While not always done well, these acts of public dissent are a significant positive sign for democracy, as they reflect people actively caring about and working to improve their lives and those of others around them. Problematically, however, many of these protests are narrowly aligned with specific political parties and ideologies that seem to constantly be in conflict with one another rather than willing to work together in collaboration or compromise. Some people have begun to see the common good as no longer feasible, believing instead that we must settle for figuring out how to mediate adversarial views. ${ }^{52}$ Relatedly, political divides in Washington and in party ideology amongst everyday citizens have grown more polarized. ${ }^{53}$ And while results of a national Gallop Poll suggest that most citizens want compromise between political leaders, they don't believe it will happen. ${ }^{54}$ Additionally, research on youth tells us that "millennials favor collaboration and disapprove of cutthroat competition." 55 They prefer polite and rational consensus on policy matters, as opposed to the loud and bitter arguments often heard between politicians or political commentators. They like leaders who strike compromises.

Given all of these contextual factors, schools should cultivate habits of collaboration and compromise as proclivities to work together, exchange ideas, and build and negotiate solutions. These habits involve an inclination toward social action and privileging of the common good, which are best nurtured through experiences that allow children to try them out through group projects that tackle real problems in the school or community. Democratic education scholar and proponent Roger Sehr claims that these types of projects "give students invaluable experience in wrestling with the obstacles that come up in working with others to define public problems, locate sources of the problems, and confront the power structures that allow the problems to exist." ${ }^{56}$ Each of these efforts, ultimately leading to social and political action, often requires collaboration and compromise. Teachers might craft situations-say the selection of a class treat and the conditions for earning it-where working together to forge consensus better serves all members of the class than simply rewarding those who are the most powerful or persuasive.

\section{Deliberation}

While many stereotypes of youth portray them as uncaring and disconnected, research actually shows that many of them enjoy prolonged conversations about 
complex topics with social implications. ${ }^{57}$ Whereas many competing political groups tend to shout hard and fast propositions at one another, youth actually desire deliberation across differences. Schools provide one of the few institutions where students can engage in extended discussions about important social issues and can be guided through the process of reaching decisions and implementing them. However, social studies classrooms, where such deliberation is most likely to occur, face increasing cuts in daily school time as emphasis is shifted to other tested subject areas. ${ }^{58}$

Philosopher of education Harry Brighouse describes the habit of deliberation as a "disposition to engage in political participation in a spirit of respect and a willingness to engage in public reasoning." 59 This public reasoning moves beyond merely asserting preferences through depositions or voting, to grappling with public problems-naming them, seeking multiple perspectives on them, considering their implications, and debating how best to address them. Philosopher Noelle McAfee explains, "Instead of seeing politics as bargaining about preferences, people see it as a difficult matter of deciding what kinds of communities they are making for themselves. Instead of merely preferring, deliberators choose. ${ }^{160}$ Whereas some contemporary theorists, inspired by Dewey's work, celebrate the process of choosing within deliberative democracy as a rule-guided form of reason-based communicating (especially those aligned with Jurgen Habermas), the habit of deliberation I am depicting here is more like what Talisse might call a "deliberative virtue" insofar as it guides the spirit of deliberation without laying out a precise map. ${ }^{61}$

The habit of deliberation, then, is a bent toward figuring out problems collectively through discussion. It propels citizens to seek input from others, especially people different from themselves, and to truly listen to them. However, Green again warns of

American culture's tendency to substitute dismissal, ridicule, and even shouting down others' ideas for democratic dialogue of the kind that would actually allow people to listen to and learn from one another. Our culture fosters these shared bad habits through political talk shows that too often turn into shouting matches, political 'debates' in which participants merely repeat 'sound bites' and insult one another instead of proposing serious public policies, real-life events and reality-based dramas in which firms and families rely on the courts and adversarial attorneys to resolve their differences instead of talking with one another, and a pervasive popular culture motif in music, television, and movies of treating a willingness to resort to physical violence as the meaning of strength and personal resolve. ${ }^{62}$

Additionally, many Americans choose to wall themselves off from those they perceive to be different or a threat to themselves by living in gated communities or confining themselves to locked urban apartments. They shy away from discussion and exchange with others, especially those who may hold different worldviews. 
Listening, which is integral to deliberation, must not be narrowly selective. Rather, citizens must seek out and overtly welcome and include a wide array of perspectives on issues. The word "democracy" itself stems from this understanding, for it is the inclusion of everyone (demos) in the running of society (kratein) ${ }^{63}$ Achieving healthy democracy requires openness to different ideas-ideas that may change the way we live and think. Dewey adds, "To cooperate by giving differences a chance to show themselves because of the belief that the expression of difference is not only a right of the other persons but is a means of enriching one's own life-experience, is inherent in the democratic personal way of life." ${ }^{34}$ Habits of deliberation, then, include a proclivity to seek out alternative ideas and to try to envision the world from new perspectives. Additionally, Pappas further defines the open-mindedness underlying the habit of deliberation I am depicting: "Given the variety of forms open-mindedness takes, and since it is not merely an intellectual trait, it is more appropriate to describe this virtue in terms of a general attitude, one Dewey describes as an attitude of hospitality toward the new. To be open is to be free from rigidity and fixity, but 'it is something more active and positive than these words suggest. It is very different than empty-mindedness' (LW 8:136). It is a receptivity and plasticity that comes from an active accessibility, from 'alert curiosity and spontaneous outreaching for the new' (LW 8:136). ${ }^{365}$

Studies of urban minority-populated schools reveal some alarming patterns. Children are often discouraged from talking about social issues, or even interacting with one another, often out of fear that fights or misbehavior may result, or out of a belief that such interaction would detract from individual students' abilities to do well on mandated tests. ${ }^{66}$ In her study of such schools, Carole Hahn found the following:

Three middle school teachers in different urban schools with largely African American populations commented that it was difficult to teach about democracy and speaking one's opinion when the atmosphere of the school worked against that. They said that although they encourage their students to speak out, many of their colleagues told students to be quiet, listen, and take notes or work on assignments at their seats. Furthermore, the students had to be quiet in the halls and the lunchroom, where a 'quiet lunch' policy was enforced. A teacher in another part of the country also expressed concern that when she taught in one urban school, 'there was no sense of responsibility put on the kids other than to be in class and to be on time. What the administrators in our building were most concerned about was order, and the last thing they wanted was for kids to speak out on issues. ${ }^{67}$

School practices like these may prevent their graduates from becoming active participants in democracy by failing to cultivate habits of deliberation, public reasoning for one's views, and the ability to work well with others.

Under such conditions, it is more important than ever that teachers provide experiences that allow for the expression of student voice, demonstrate for students 
how to carefully listen to one another, and highlight the benefits gained from doing so. These might include group activities that cannot be successfully completed without the participation of all members or without carefully gathering information from people outside the group. Additionally, teachers might require students to reach a consensus on how best to handle a real social problem in the school, providing children the opportunity to influence policy or practice in the school and modeling how to do so through the gathering of ideas, the use of persuasive public reasoning, and the choosing of courses of action together. Finally, teachers should engage students in dialogue and metacognitive discussions about how the dialogues work, highlighting fruitful exchanges, as well as moments of silencing or ignoring the input of certain students.

\section{Analysis and Critique}

Many of our most pressing social and political issues involve struggles over cultural recognition, resources, and power: gay marriage, immigration, and health care reform, to name a few. Looking at these issues historically reveals that perpetuating the status quo has led to ongoing injustices for many citizens. Rather than remaining complacent in the face of these social and political struggles, youth need habits of analysis and critique that engage inquiry in action, especially in acts of political dissent. Certainly, we have seen a recent proliferation of dissent on our street corners and in our town halls. While some of these protests have energized youth, motivated previously uninterested citizens, or led to significant impact on legislation and leadership, others have been relatively ineffective or outright destructive. Many young people experience frustration with social and political issues but lack the know-how or desire to engage in political dissent well. They are unprepared not only for an ideal democracy where dissent is carefully employed to improve social life, but also democracy as it is currently being lived outside school walls, where dissent is alive but floundering ${ }^{68}$

Habits of analysis and critique form the basis of dissenting action. They shape how we perceive and interpret the world around us, sensitizing us to moments of injustice and beckoning us to examine the causes and implications of social and political struggles. They are dispositions to question and challenge, rather than to accept and obey. Most obviously, analysis and critique help to shape our ideas and impressions. But these habits do not stop at thought; rather, they are calls to action, to do something to make the world better, fairer, or more just. Dewey describes the education of citizens toward this type of social improvement in this way: "A society which makes provision for participation in its good of all its members on equal terms and which secures flexible readjustment of its institutions through interaction of the different forms of associated life is in so far democratic. Such a society must have a type of education which gives individuals a personal interest in social relationships and control, and the habits of mind which secure social changes without introducing disorder." ${ }^{9}$ 
These habits, with their links to dissenting action, distinguish the more complete picture of Dewey's vision of citizenship education that I am painting here. Westheimer and Kahne have offered broad categories of citizenship education. It would seem that Dewey's emphasis on active civic life and volunteerism might render his view of citizenship education aligned with the "participatory citizen" model that Westheimer and Kahne describe. ${ }^{70}$ But when the habits of critique and analysis are taken into account, Dewey's desired citizen is more akin to what they call "a justice-oriented citizen," someone who engages in cultural criticism and social movements. Certainly, for Dewey, the role of cultural critic, especially one who employs a reconstruction approach with a spirit of meliorism and who is skeptical about leadership's use of power, is key to being a good dissenter.

Dewey demonstrated this type of citizenship himself. For example, he employed analysis and critique of blind patriotism and military institutions on campus in his article, "Our Education Ideal in Wartime." to form the Committee on Militarism in Education-a public with shared concerns - to distribute pamphlets and raise awareness about the negative impact of military organizations on school campuses. Notably, while Dewey's actions were typically Left-leaning endeavors, engaging in cultural criticism and social movements is not necessarily a politically liberal undertaking. Certainly the recent rise of the Tea Party reveals the ability of these tools to be employed in ways that lead to or embrace conservative views. Importantly, the habits of analysis and critique themselves are not politically affiliated, even if the conclusions they reach may be.

Teachers can provide debate activities and encounters with controversial social issues to provoke students to engage critique, all the while guiding their skills of cultural analysis through supporting a spirit of criticality that asks tough questions to reveal how power works in social situations and how it privileges some people and not others. Teachers might also take their students outside school walls to learn more about the dissenting movements currently unfolding, and to engage in analysis of what they are doing well and what they are not, as well as how they are shaping democracy.

Critique entails the Deweyan process of inquiry, where observations are made, facts are gathered, and participants discuss their experiences. But it is slow in reaching a judgment, carefully considering the genealogy of conditions of a policy or practice in question and how people and power are implicated in it. ${ }^{72}$ David Sehr recommends a similar approach:

Students can begin their inquiries by examining their own life experiences. They can be asked to recall situations of injustice they have either experienced or witnessed. They can then work together to analyze the social causes and power relations involved in those situations, how they responded to them, and other ways they might intervene to challenge injustice in similar situations in the future. ${ }^{73}$

\section{E\&C Education and Culture}


Finally, to be an effective critic and to use one's criticism to produce action in the world, one must have a good understanding of language. Teachers should engage students in activities that help them understand how language works to wield power, to bring civic unity, and to persuade others of political views. This likely would entail crafting and delivering arguments for one's positions on issues that genuinely impact social living.

Hope

In 2008, Barack Obama rallied the majority of the country around his campaign using the word "hope" under his iconic image. ${ }^{74} \mathrm{He}$ spoke of great changes ahead and making our country a better place. Yet only a short time later, President Obama was questioned by a fourth grader who was concerned about growing anger toward political leaders. Obama responded, "If you're watching TV lately, it seems like everyone is just getting mad all the time." ${ }^{75}$ Indeed, we have witnessed increased anger and frustration in traditionally civil spaces of democracy, including our town halls and street corners. ${ }^{76}$ This situation has magnified youths' dissatisfaction with the political spin and adversarial nature of political life in America. ${ }^{77}$ Additionally, some poor minorities have experienced a loss of agency, feeling as if they are unable to contribute to political life, leading them to withdraw from it. ${ }^{78}$ In this context, Americans need hope for a better functioning democracy and better social living. Many people problematically understand hope to be a trait of individuals who are optimists, believers that things will work out for the best regardless of the current limitations. But for Dewey, hope is a way of living aligned with meliorism, "the idea that at least there is a sufficient basis of goodness in life and its conditions so that by thought and earnest effort we may constantly make better things." ${ }^{39}$ It entails action and effort even in the face of current limitations, and a confidence that they can be overcome. In this way, we see why it is worthwhile to understand hope as a habit that entails action-especially actions that engage proclivities toward change and attitudes that move us toward desirable objects or states of affairs.

Hope is not merely an optimistic belief or rosy outlook. It entails what Richard Bernstein saw as a central characteristic of Deweyan pragmatism: "sensitivity to radical contingency and change." ${ }^{80}$ This includes not being complacent with social living, but striving to improve it by revealing problems, seeking inclusive input on those problems, and envisioning and implementing solutions. In terms of democracy, a habit of hope helps us recognize that democracy is not fixed but constantly changing as the needs and demographics of its citizens change; and that we, therefore, can always make changes to associated living to improve such life for ourselves and others. Pappas adds, "Democracy is a way of life that tries and hopes for salvation from within this process. Non-democratic systems and communications do not have the built-in means to improve themselves or respond adequately to change." $\$ 1$ 
Inspired by Dewey, philosopher of education Maxine Greene defines freedom as "the capacity to surpass the given and look at things as if they could be otherwise." ${ }^{82}$ To be free in a democracy, then, depends on hopeful individuals who work together to enact their visions for change. These people put forward visions of better social living that guide and sustain other people. Sometimes, injustice limits these visions. It is the habit of hope that goads one to speak out against injustice and to offer better and alternative ways of living. Speaking out draws upon habits of analysis and critique described above and may evoke feelings of frustration, but it should be done with a spirit of transformation.

Meliorism should be a criterion directing analysis and critique. ${ }^{83}$ Henry Giroux adds, "Educated hope is a subversive force. In opposition to those who seek to turn hope into a new slogan or who punish and dismiss efforts to look beyond the horizon of the given, educators need to resurrect a language of resistance and possibility, a language in which hope becomes anticipatory rather than messianic, mobilizing rather than therapeutic." ${ }^{\prime 4}$ This subversive and transformative habit is linked to political agency. Pragmatist Patrick Shade explains that "hope signifies the growth of agency." ${ }^{35}$ In other words, habits of hope provide us the support structure and intelligent direction that enable us to become agents capable of changing ourselves and our world. Habits of hope move us from being merely reactionary respondents to being active agents.

Stories offer a helpful tool for nurturing the habit of hope in schools. Stories, especially when presented under the guidance of teachers, help students to see how their worlds could be different. Stories of struggle and success develop children's sensitivity to the lives of other people and provide examples of creative solutions that others have crafted to solve their social problems. When students see how others have worked to improve their lives, they are provided fodder for how they might try out ideas in their own situations. But more than just reading the stories of others, students should be encouraged to create stories as well. Storytelling is an experience that allows students to practice imagination and to envision how the world might be made better: "It also offers a counterforce to fatalistic statements children are likely to hear, including utterances such as, 'that's the way it's always been and that's the way it always will be' or 'we tried to fix it before but it didn't work then and it won't work now.' Story construction allows students to oppose such paralyzing beliefs with evidence, even if it comes at the level of imagination. ${ }^{\$ 86}$ When stories are constructed in groups, children can talk together about their understandings of the world and how it could be improved, and collaborate in constructing an alternative through deliberation.

\section{CONCLUSION}

Building on Dewey's understanding of habit formation and change as key elements of political agency, I have offered here some suggestions for democratic habits that 
our schools might nurture to address current social and political contexts and problems. Schools can support these habits not only through their curriculum content, but also in pedagogy and policy. Although not an exhaustive list, these habits-citizenship as shared fate, collaboration and compromise, deliberation, analysis and critique, and hope-are key components of successful living alongside equality, communication, participation and inclusion. I anticipate that these habits will also likely carry us through struggles in the future and can themselves be adapted to our changing needs as the shape and practice of democracy unfolds.

\section{BiBLIOGRAPHY}

Applebaum, Barbara. "Critique of Critique: On Suspending Judgment and Making Judgment." In Philosophy of Education. Edited by Robert Kunzman. Urbana, IL: University of Illinois Press, 2011.

Ben-Porath, Sigal. Citizenship Under Fire: Democratic Education in Times of Conflict. Princeton, NJ: Princeton University Press, 2009.

- - . "Deferring Virtue: The New Management of Students and the Civic Role of Schools." Theory and Research in Education 11, no. 2 (2013): 111-28.

Biesta, Gert. "Education and the Democratic Person: Towards a Political Conception of Democratic Education." Teachers College Record 109, no. 3 (2007): 740-69.

- - Good Education in an Age of Measurement: Ethics, Politics, Democracy. Boulder: Paradigm, 2010.

- - Sporadic Democracy: Education, Democracy and the Question of Inclusion. Accessed August 4, 2013. https://dspace.stir.ac.uk/bitstream/1893/996/1 /Sporadic\%20democracy_\%20Education,\%20Democracy\%20and\%20the\%20 Question\%20of\%20Inclusion.pdf.

“Boy Asks Obama, 'Why Do People Hate You?"' Town Hall Meeting led by Barrack Obama at the University of New Orleans, October 15, 2009. Accessed August 4, 2013. http://www.youtube.com/watch?v=Py15owTneag.

Brighouse, Harry. On Education. New York: Routledge, 2005.

Butler, Judith. "What Is Critique? An Essay on Foucault's Virtue." In The Political. Edited by David Ingram. Oxford: Blackwell, 2002.

Candisky, Catherine. "Parkinson's Patient Gains National Attention from Public Health-Care Rally Confrontation." Columbus Dispatch. March 19, 2010.

Claes, Ellen, and Marc Hooghe. "Citizenship Education and Political Interest." In Civic Education and Youth Political Participation, edited by M. Print and H. Milner. Rotterdam: Sense Publishers, 2009.

Dewey, John. "Creative Democracy-The Task Before Us." In The Later Works, edited by Jo Ann Bodyston, 224-30. Carbondale, IL: Southern Illinois University Press, 1976.

- - . "Democracy and Education." MW 1899-1924, Vol 9. Edited by Jo Ann Boydston. Carbondale: Southern Illinois University Press, 1980. 
-_- Democracy and Education. New York: The Free Press, 1966[1916].

-_- Experience and Education. Indianapolis: Kappa Delta Pi, 1998.

_-_. Human Nature and Conduct. 1922; reprint, Mineola, NY: Dover, 2002.

_-_. "My Pedagogic Creed, Article I." School Journal, Vol. 54, 77-80. January, 1897.

_-_. "Our Education Ideal in Wartime." The New Republic 6, 283-4, April 15, 1916.

- - . "The Challenge of Democracy to Education." In John Dewey: The Later

Works, 1925-1953. Volume 11: 1935-1937, edited by Jo Ann Boydston, 181-90.

Carbondale and Edwardsville: Southern Illinois University Press, 1987a[1937].

Eldridge, Michael. Transforming Experience. Nashville, TN: Vanderbilt University

Press, 1998.

Foucault, Michel. "Questions of Method." In The Foucault Effect: Studies in

Governmentality with Two Lectures by and an Interview with Michel Foucault.

Edited by Graham Burchell, Colin Gordon, and Peter Miller. Chicago:

University of Chicago Press, 1991.

Garcia, David, Rebecca Barber, and Alex Molnar. "Profiting from Public Education:

Education Management Organizations and Student Achievement.” Teachers

College Record 111, no. 5 (2009): 1352-79.

Giroux, Henry. America on the Edge. New York: Palgrave MacMillan, 2006.

Green, Judith. Deep Democracy. Lanham, MD: Rowman \& Littlefield Press, 1999.

-_- Pragmatism and Social Hope: Deepening Democracy in Global Contexts.

New York: Columbia University Press, 2008.

Greene, Maxine. The Dialectic of Freedom. New York: Teachers College Press, 1988. Hahn, Carole L. "Education for Democratic Citizenship: One Nation's Story." In Education for Democracy: Contexts, Curricula, Assessments. Edited by Walter C. Parker. Greenwich, CT: Information Age Publishing, 2002.

Hildreth, Roudy W. Living Citizenship: John Dewey, Political Theory, and Civic Engagement. Dissertation, University of Minnesota, 2005.

Howe, Neil, and Reena Nadler. "Yes We Can: The Emergence of Millennials as

a Political Generation." In Next Social Contract Initiative. New America Foundation, 2009.

Isenstadt, Alex. “Town Halls Gone Wild.” Politico. July 31, 2009.

Johnston, James Scott. Inquiry and Education. Albany, NY: State University of New York Press, 2006.

Journell, Wayne. "Teaching the 2008 Presidential Election at Three Demographically

Diverse Schools." Educational Studies 47, no. 2 (2011).

Kahne, Joseph, and Ellen Middaugh. "Democracy for Some: The Civic Opportunity Gap in High School." In Engaging Young People in Civic Life, edited by James Youniss and Peter Levine, 29-58. Nashville, TN: Vanderbilt University Press, 2009. _- _. "High Quality Civic Education: What Is It and Who Gets It?" Social Education 72 (2008): 34-9. 
Kloppenberg, James T. Reading Obama: Dreams, Hope, and the American Political Tradition. Princeton, NJ: Princeton University Press, 2011.

Koopman, Colin. Pragmatism as Transition: Historicity and Hope in James, Dewey, and Rorty. New York: Columbia University Press, 2009.

Labaree, David. "Public Goods, Private Goods: The American Struggle over Educational Goals," American Educational Research Journal 34, no. 1 (1997): 39-81.

Lacireno-Paquet, Natalie, Michele Moser, and Jeffrey Henig. "Creaming Versus Cropping: Charter School Enrollment Practices in Response to Market Incentives." Educational Evaluation and Policy Analysis 24, no. 2 (2002): 145-58.

Lopez, Mark Hugo and Emily Hoban Kirby. "U.S. Civics Instruction: Content and Teaching Strategies." The Center for Information and Research on Civic Learning and Engagement (2007).

McAfee, Noelle. Democracy and the Political Unconscious. New York: Columbia University Press, 2008. 167.

Murrer, Jennifer. "Instructional Time in Elementary Schools: A Closer Look at Changes for Specific Subjects," Center on Education Policy, 2008.

Page, Susan. "Poll: Most Want Obama, GOP to Work Together." USA Today. Last modified January 18, 2011. http://usatoday30.usatoday.com/news /washington/2011-01-17-poll-obama-house_N.htm.

Pappas, Gregory Fernando. John Dewey's Ethics: Democracy as Experience. Bloomington, IN: Indiana University Press, 2008.

"Partisan Polarization Surges in Bush, Obama Years-Trends in American Values: 1987-2012." Pew Research Center for the People \& the Press. Last modified June 4, 2012. http://www.people-press.org/2012/06/04/section-1-understanding -the-partisan-divide-over-american-values/.

Ralston, Shane. "A More Practical Pedagogical Ideal: Searching for a Criterion of Deweyan Growth," Educational Theory, vol. 61, no. 3 (July 2011): 351-64.

Roholt, Ross Velure, R.W. Hildreth, and Michael Baizerman. Becoming Citizens (New York: Routledge, 2009).

Saltman, Kenneth. The Edison Schools: Corporate Schooling and the Assault on Public Education. New York: Routledge, 2005.

Sehr, David. Education for Public Democracy. New York: SUNY Press, 1999.

Shade, Patrick. Habits of Hope: A Pragmatic Theory. Nashville, TN: Vanderbilt University Press, 2001.

Sharec, Carly. "Hall School Leaders Want to Revamp Social Studies: Board Calls for Action Committee to Study, Recommend Changes in Curriculum." Gainesville Times. Last modified July 22, 2013. http://www.gainesvilletimes.com/section/6 /article/86454/.

Stein, Sam. “Tea Party Protests: 'Ni ${ }^{* *}$ er, 'Fa ${ }^{* *}$ ot' Shouted at Members of Congress." Huffington Post. March 20, 2010. 
Stitzlein, Sarah. Breaking Bad Habits of Race and Gender: Identity Transformation in Schools. Lanham MD: Rowman and Littlefield, 2008.

- - _. "Citizenship Education in For-Profit Charter Schools?" Journal of Curriculum Studies 45, no. 2 (2013): 251-76.

-_- Teaching for Dissent: Citizenship Education and Political Activism. Boulder CO: Paradigm Press, 2012.

Talisse, Robert. Democracy after Liberalism. New York: Routledge, 2004.

Waks, Leonard J. "How Globalization Can Cause Fundamental Curriculum Change: An American Perspective." Journal of Educational Change, no. 4 (2003): 383-418. Wells, Amy, Julie Slayton, and Janelle Scott. "Defining Democracy in the Neoliberal Age: Charter School Reform and Educational Consumption." American Educational Research Journal 39, no. 2 (2002): 337-61.

Westbrook, Robert. John Dewey and American Democracy. Ithaca NY: Cornell University press, 1993.

Westheimer, Joel. Pledging Allegiance: The Politics of Patriotism in America's Schools. New York: Teachers College Press, 2004.

Westheimer, Joel, and Joseph Kahne. "What Kind of Citizen? The Politics of Educating for Democracy." American Educational Research Journal 41, no. 2 (2004): 237-69.

Williams, Melissa S. "Citizenship as Identity, Citizenship as Shared Fate, and the Functions of Multicultural Education." In Citizenship and Education in LiberalDemocratic Societies: Teaching for Cosmopolitan Values and Collective Identities, edited by K. McDonough and W. Feinberg. Oxford, UK: Oxford University Press, 2003.

\section{Notes}

1. Ross Velure Roholt, R.W. Hildreth, and Michael Baizerman, Becoming Citizens (New York: Routledge, 2009). Roudy Hildreth, Living Citizenship: John Dewey, Political Theory and Civic Engagement, Dissertation, University of Minnesota, 2005. James Scott Johnston, Inquiry and Education, (Albany, NY: State University of New York Press, 2006). Robert Westbrook, John Dewey and American Democracy (Ithaca NY: Cornell University press, 1993), 317; Ellen Claes and Marc Hooghe, "Citizenship Education and Political Interest," in Civic Education and Youth Political Participation, ed. M. Print and H. Milner (Rotterdam: Sense Publishers, 2009).

2. Westbrook, John Dewey and American Democracy. Michael Eldridge, Transforming Experience (Nashville, TN: Vanderbilt University Press, 1998), 70-85. I share Roudy Hildreth's critique of Westbrook's claim. I also feel that while Dewey may not have offered a specific and detailed directive for how to achieve citizenship education, the overarching philosophy of education Dewey espouses is thoroughly democratic. Hildreth, 2005, 7.

3. John Dewey, Human Nature and Conduct (1922; reprint, Mineola, NY: Dover, 2002).

4. Neil Howe and Reena Nadler, "Yes We Can: The Emergence of Millennials as a Political Generation," in Next Social Contract Initiative (New America Foundation, 2009). 
5. Abby Kiesa, Alexander P. Orlowski, Peter Levine, Deborah Both, Emily Hoban Kirby, Mark Hugo Lopez, and Karlo Barrios Marcelo, "Millenials Talk Politics: A Study of College Student Political Engagement” (CIRCLE, 2007), 9.

6. Ibid, 9 .

7. Judith Green, Pragmatism and Social Hope: Deepening Democracy in Global Contexts (New York: Columbia University Press, 2008), 203.

8. Gregory Fernando Pappas, John Dewey's Ethics: Democracy as Experience (Bloomington, IN: Indiana University Press, 2008) 307.

9. John Dewey, “The Challenge of Democracy to Education," in John Dewey: The Later Works, 1925-1953. Volume 11: 1935-1937, ed. Jo Ann Boydston (Carbondale and Edwardsville: Southern Illinois University Press, 1987a[1937]), 182.

10. John Dewey, Democracy and Education (New York: The Free Press, 1966[1916]), 87.

11. James Scott Johnston, Inquiry and Education (Albany, NY: SUNY Press, 2006), 183.

12. Ibid., 192.

13. John Dewey, "Creative Democracy-The Task Before Us" in The Later Works, ed. Jo Ann Boydston. (Carbondale: Southern Illinois University Press, 1976) 224-30.

14. Dewey. Human Nature and Conduct, 25.

15. Ibid., 67.

16. Ibid., 177.

17. Ibid.

18. Dewey, Democracy and Education, 48.

19. Sarah Stitzlein, Breaking Bad Habits of Race and Gender: Identity Transformation in Schools (Lanham MD: Rowman and Littlefield, 2008), 21.

20. Dewey, Human Nature and Conduct, 52.

21. Robert Talisse, Democracy after Liberalism (New York: Routledge, 2004), Gregory Fernando Pappas, John Dewey's Ethics: Democracy as Experience (Bloomington, IN: Indiana University Press, 2008), Shane Rawlston, "A More Practical Pedagogical Ideal: Searching for a Criterion of Deweyan Growth," Educational Theory, vol. 61, no. 3 (July 2011): 351-64.

22. Pappas, 125.

23. John Dewey, "Democracy and Education," $M W$ 1899-1924, Vol 9, ed. Jo Ann Boydston (Carbondale: Southern Illinois University Press, 1980), 367.

24. Ralston, 356.

25. Pappas, 155.

26. Gert Biesta, "Education and the Democratic Person: Towards a Political Conception of Democratic Education," Teachers College Record 109, no. 3 (2007): 742.

27. For more, see Biesta, "Education and the Democratic Person."

28. Dewey, "Creative Democracy," 226.

29. Robert Talisse, Democracy after Liberalism (New York: Routledge, 2004), 123.

30. Ibid., 229.

31. John Dewey, Experience and Education (Indianapolis: Kappa Delta Pi, 1998), 31.

32. Ralston, 364. Talisse, 116.

33. Johnston, 190.

34. Dewey, Democracy and Education, 26; Green, Pragmatism and Social Hope, 68.

35. Gert Biesta, Good Education in an Age of Measurement: Ethics, Politics, Democracy (Boulder: Paradigm, 2010). 
36. Judith Green, Deep Democracy (Lanham, MD: Rowman \& Littlefield Press, 1999), 62.

37. Biesta, Good Education, 103-4.

38. John Dewey, "My Pedagogic Creed, Article I," School Journal Vol. 54 (January 1897), 77-80.

39. Note removed.

40. Leonard J. Waks, "How Globalization Can Cause Fundamental Curriculum Change: An American Perspective." Journal of Educational Change, 4 (2003).

41. Joel Westheimer, Pledging Allegiance: The Politics of Patriotism in America's Schools (New York: Teachers College Press, 2004), 175-79.

42. Sarah Stitzlein, Teaching for Dissent: Citizenship Education and Political Activism (Boulder CO: Paradigm Press, 2012), 105.

43. Joseph Kahne and Ellen Middaugh, "Democracy for Some: The Civic Opportunity Gap in High School," in Engaging Young People in Civic Life, ed. James Youniss and Peter Levine (Nashville, TN: Vanderbilt University Press, 2009), 122.

44. Carly Sharec, "Hall School Leaders Want to Revamp Social Studies: Board Calls for Action Committee to Study, Recommend Changes in Curriculum," Gainesville Times, last modified July 22, 2013, http://www.gainesvilletimes.com/section/6 /article/86454/.

45. I borrow this term from others, including Sigal Ben-Porath, Citizenship Under Fire: Democratic Education in Times of Conflict (Princeton, NJ: Princeton University Press, 2009), 48; and Melissa S. Williams, "Citizenship as Identity, Citizenship as Shared Fate, and the Functions of Multicultural Education," in Citizenship and Education in Liberal-Democratic Societies: Teaching for Cosmopolitan Values and Collective Identities, ed. K. McDonough and W. Feinberg. (Oxford, UK: Oxford University Press, 2003).

46. Green, Deep Democracy, 76.

47. Pappas, 233.

48. Dewey, Creative Democracy, 228.

49. Ibid.

50. David Garcia, Rebecca Barber, and Alex Molnar, "Profiting from Public Education: Education Management Organizations and Student Achievement," Teachers College Record 111, no. 5 (2009): 1352-79; Natalie Lacireno-Paquet, Michele Moser, and Jeffrey Henig, "Creaming Versus Cropping: Charter School Enrollment Practices in Response to Market Incentives," Educational Evaluation and Policy Analysis 24, no. 2 (2002): 145-58; Kenneth Saltman, The Edison Schools: Corporate Schooling and the Assault on Public Education (New York: Routledge, 2005); Sarah M. Stitzlein, "Citizenship Education in For-Profit Charter Schools?” Journal of Curriculum Studies 45, no. 1 (2013); Amy Wells, Julie Slayton, and Janelle Scott, "Defining Democracy in the Neoliberal Age: Charter School Reform and Educational Consumption." American Educational Research Journal 39, no. 2 (2002): 337-61.

51. David Labaree, "Public Goods, Private Goods: The American Struggle over Educational Goals," American Educational Research Journal 34, no. 1 (1997): 39-81.

52. Green, Deep Democracy.

53. "Partisan Polarization Surges in Bush, Obama Years-Trends in American Values: 1987-2012," Pew Research Center for the People \& the Press, last modified June 4, 2012 http://www.people-press.org/2012/06/04/section-1-understanding-thepartisan-divide-over-american-values/. 
54. Susan Page, "Poll: Most Want Obama, GOP to Work Together," USA Today, last modified January 18, 2011, http://usatoday30.usatoday.com/news/washington/2011 -01-17-poll-obama-house_N.htm.

55. Howe and Nadler, "Yes We Can."

56. David Sehr, Education for Public Democracy (New York: SUNY Press, 1999), 95-6.

57. Howe and Nadler, "Yes We Can."

58. Mark Hugo Lopez and Emily Hoban Kirby, "U.S. Civics Instruction: Content and Teaching Strategies," The Center for Information and Research on Civic Learning and Engagement (2007); Jennifer Murrer, "Instructional Time in Elementary Schools: A Closer Look at Changes for Specific Subjects," Center on Education Policy (2008).

59. Harry Brighouse, On Education (New York: Routledge, 2005), 67.

60. Noelle McAfee, Democracy and the Political Unconscious (New York: Columbia University Press, 2008), 167.

61. Talisse would likely further link the habit of deliberation to the virtues of honesty, modesty, charity, and integrity in Democracy after Liberalism, 113. Also see Pappas, 254.

62. Green, Pragmatism and Social Hope, 235.

63. For more, see Gert Biesta, Sporadic Democracy: Education, Democracy and the Question of Inclusion, accessed August 4, 2013, https://dspace.stir.ac.uk/bitstream /1893/996/1/Sporadic\%20democracy_\%20Education,\%20Democracy\%20and\%20 the\%20Question\%20of\%20Inclusion.pdf.

64. Dewey, Creative Democracy, 228.

65. Pappas, 188.

66. Sigal Ben-Porath, "Deferring Virtue: The New Management of Students and the Civic Role of Schools," Theory and Research in Education 11, no. 2 (2013); Wayne Journell, "Teaching the 2008 Presidential Election at Three Demographically Diverse Schools," Educational Studies 47, no. 2 (2011); Joseph Kahne and Ellen Middaugh, "High Quality Civic Education: What Is It and Who Gets It?” Social Education 72 (2008).

67. Carole L. Hahn, "Education for Democratic Citizenship: One Nation's Story," in Education for Democracy: Contexts, Curricula, Assessments, ed. Walter C. Parker (Greenwich, CT: Information Age Publishing, 2002), 75.

68. Stitzlein, Teaching for Dissent.

69. Dewey, Democracy and Education (1916), 105.

70. Joel Westheimer and Joseph Kahne, "What Kind of Citizen? The Politics of Educating for Democracy," American Educational Research Journal 41, no. 2 (2004): 237-69.

71. John Dewey, "Our Education Ideal in Wartime," The New Republic 6 (April 15, 1916): 283-284.

72. Michel Foucault, "Questions of Method," in The Foucault Effect: Studies in Governmentality with Two Lectures by and an Interview with Michel Foucault, ed. Graham Burchell, Colin Gordon, and Peter Miller (Chicago: University of Chicago Press, 1991); Judith Butler, "What Is Critique? An Essay on Foucault's Virtue," in The Political, ed. David Ingram (Oxford: Blackwell, 2002); Barbara Applebaum, "Critique of Critique: On Suspending Judgment and Making Judgment," in Philosophy of Education, ed. Robert Kunzman (Urbana, IL: University of Illinois Press, 2011).

73. Sehr, Education for Public Democracy, 96.

74. I recognize that other scholars of pragmatism have speculated as to the pragmatist roots of President Obama, including his use of hope, particularly in Contemporary 
Pragmatism, volume 8, number 2, 2011. I believe this is a worthwhile avenue of analysis, but feel that it is beyond the scope of this paper to address it here.

75. "Boy Asks Obama, 'Why Do People Hate You?"' Town Hall Meeting Led by Barrack Obama at the University of New Orleans, October 15, 2009. Accessed August 4, 2013, http://www.youtube.com/watch?v=Py15owTneag.

76. Alex Isenstadt, "Town Halls Gone Wild," Politico, July 31, 2009; Sam Stein, “Tea Party Protests: 'Ni ${ }^{\star *}$ er, ' $\mathrm{Fa}^{\star *}$ ot' Shouted at Members of Congress,' Huffington Post, March 20, 2010; Catherine Candisky, "Parkinson's Patient Gains National Attention from Public Health-Care Rally Confrontation," Columbus Dispatch, March 19, 2010.

77. Howe and Nadler, "Yes We Can."

78. Green, Deep Democracy, ix.

79. Dewey quoted in Patrick Shade, Habits of Hope: A Pragmatic Theory (Nashville, TN: Vanderbilt University Press, 2001), 17.

80. In James T. Kloppenberg, Reading Obama: Dreams, Hope, and the American Political Tradition (Princeton, NJ: Princeton University Press, 2011) 133.

81. Pappas, John Dewey's Ethics: Democracy as Experience 293.

82. Maxine Greene, The Dialectic of Freedom (New York: Teachers College Press, 1988), 3.

83. For more, see Colin Koopman, Pragmatism as Transition: Historicity and Hope in James, Dewey, and Rorty (New York: Columbia University Press, 2009).

84. Henry Giroux, America on the Edge (New York: Palgrave MacMillan, 2006), 37.

85. Shade, Habits of Hope, 22.

86. Stitzlein, Teaching for Dissent, 161.

Sarah M. Stitzlein is associate professor of Philosophy of Education and Curriculum Theory at the University of Cincinnati. Email: Sarah.Stitzlein@uc.edu. 